E3S Web of Conferences 1, 15007 (2013)

DOI: $10.1051 / \mathrm{e} 3$ sconf/20130115007

(c) Owned by the authors, published by EDP Sciences, 2013

\title{
The effect of different water managements on rice arsenic content in two arsenic-spiked soils
}

\author{
H. Y. Chang ${ }^{1}$ and Z. S. Chen ${ }^{2}$ \\ ${ }^{1}$ Department of Agricultural Chemistry, National Taiwan University, Taipei 10617, TAIWAN, r99623032@ntu.edu.tw \\ ${ }^{2}$ Department of Agricultural Chemistry, National Taiwan University, Taipei 10617, TAIWAN, soilchen@ntu.edu.tw
}

\begin{abstract}
Growing rice on arsenic (As)-contaminated paddy fields may induce high As level grain production. In order to reduce the food contamination risk, the pot experiments containing two As-spiked aging soils and four water managements were conducted to evaluate the effects of water managements on rice As content. The results indicated that As concentration of Erlin soil solution was 10 to 20 times (210-520 $\mu \mathrm{g} / \mathrm{L})$ higher than that of Pinchen soil solution $(5-20 \mu \mathrm{g} / \mathrm{L})$ at early stage of experiment (0-60 days). Aerobic water treatment will decrease As level to $30-50 \%(108-220 \mu \mathrm{g} / \mathrm{L})$ of original As concentration in Erlin soil solution. Statistic results indicated that water management was effective to reduce the rice grain As level in Erlin soil. However, the management impact was not obvious in Pinchen soil, which may be attributed to high clay or free Fe and Al content in the soil. This study suggested that keeping soil under aerobic condition for 3 weeks before rice heading can reduce the risk of rice grown at the As-contamination soil.
\end{abstract}

Key words: arsenic contamination, water management, rice grain, aerobic condition, soil solution

\section{Introduction}

Arsenic (As) and As compounds are listed in group I carcinogen in International Agency for Research on Cancer (IARC), World Health Organization (WHO). In south-west Taiwan, high level of arsenic content in groundwater were used as the drinking water source for local people and the long term arsenic containing water drinking had made endemic black-foot disease (BFD) in that area (Chen et al., 2007).

Although people drunk high level arsenic ground water no longer, the contaminated water had been used for paddy rice cultivation for long time. The As will be accumulated in soil, raise soil total arsenic level, and finally increase the possibility of high As level rice grain production (Hsu et al., 2012). To avoid the possible risk, the useful field soil management methods must be developed to reduce the risk of grain contamination if rice cultivated at As-contaminated paddy soil.

Water management has been indicated to be a possible strategy to reduce the rice grain As level. Xu et al. (2008) showed that growing paddy rice aerobically can reduce grain As content significantly. Arao et al. (2009) also indicated that rice grain As level can be reduced if the pot soil is not flooded before 3 weeks of rice heading. Therefore, it can be concluded that maintaining soil environment under the aerobic condition at specific rice growing duration would decrease the brown rice As content for those rice grown in As-contaminated soils.

The Guandu Plain, locating at northwestern Taipei, Taiwan, was found high soil total As concentration (ranged 100-500 mg/kg distributed at the rural soils of $300 \mathrm{ha}$ ) in the paddy fields ( $\mathrm{Su}$ and Chen, 2008). The investigation data indicated that contaminated brown rice may be produced from the Guandu Plain under some cultivation conditions. From the view of food safety and sustainable land, the exact field operational method for water management must be developed to prevent the high As level rice production and decrease the health risk of food contamination in this area. The objective of this study is to develop an reliable soil water management to reduce the As risk of rice grain grown in As-contaminated soil.

\section{Materials and Methods}

Two surface soils (0-15 cm depth) (Erlin and Pinchen soils) were collected on March, 2011. The soil characters were analyzed as: $\mathrm{pH}$ (soil:water $=1: 1$ ) (Thomas, 1996), organic carbon (Walkley and Black, 1934), clay content (Gee and Bauder, 1986), amorphous 
Table 1. Soil physical and chemical properties of two studied soils

\begin{tabular}{|c|c|c|c|c|c|c|c|c|c|c|}
\hline \multirow[b]{2}{*}{ Soils\# } & \multirow[b]{2}{*}{$\mathrm{pH}$} & \multirow{2}{*}{$\begin{array}{c}\text { Organic } \\
\text { matter }\end{array}$} & \multicolumn{3}{|c|}{ particle size } & \multirow[b]{2}{*}{$\mathrm{Fe}_{0}$ ๆ } & \multirow[b]{2}{*}{$\mathrm{Al}_{\mathrm{o}}$ ๆ } & \multirow[b]{2}{*}{$\mathrm{Fe}_{\mathrm{d}} \boldsymbol{q}$} & \multirow[b]{2}{*}{$\mathrm{Al}_{\mathrm{d}}$ ๆ } & \multirow[b]{2}{*}{ total As } \\
\hline & & & sand & silt & clay & & & & & \\
\hline & & & & & & $O_{-}$ & ------י & ---- & & --mg/kg-- \\
\hline Erlin & 7.64 & 22 & 392 & 403 & 205 & 3.37 & 0.75 & 9.34 & 0.77 & 8.13 \\
\hline Pinchen & 6.43 & 11.5 & 182 & 374 & 444 & 5.05 & 2.25 & 42.7 & 5.37 & 10.8 \\
\hline
\end{tabular}

\#: The name of the soil series.

П: $\mathrm{Fe}_{\mathrm{o}}$ and $\mathrm{Al}_{\mathrm{o}}$ : oxalate extractable $\mathrm{Fe}$ and $\mathrm{Al} ; \mathrm{Fe}_{\mathrm{d}}$ and $\mathrm{Al} \mathrm{d}_{\mathrm{d}}$ : $\mathrm{DCB}$ extractable $\mathrm{Fe}$ and $\mathrm{Al}$.

Table 2. Arsenic concentration of soil solution of four water management treatments during the experimental duration.

\begin{tabular}{|c|c|c|c|c|c|c|c|c|}
\hline \multicolumn{2}{|c|}{$\begin{array}{c}\text { Days after planting } \\
\text { Treatment }\end{array}$} & $1 \mathrm{st}$ & 34 th & 48th & 60th & 82 nd & 104th & 117 th \\
\hline \multirow{4}{*}{ Erlin } & CK & $212 \pm 67.4$ & $423 \pm 59.0$ & $259 \pm 123$ & $260 \pm 74.1$ & $509 \pm 198$ & $885 \pm 404$ & $912 \pm 233$ \\
\hline & A & $265 \pm 100$ & $466 \pm 57.2$ & $527 \pm 125$ & $376 \pm 82.4$ & $108 \pm 105$ & $388 \pm 275$ & $425 \pm 229$ \\
\hline & B & $312 \pm 106$ & $467 \pm 15.4$ & $524 \pm 66.6$ & $410 \pm 37.4$ & $600 \pm 82.6$ & $346 \pm 165$ & $229 \pm 117$ \\
\hline & $\mathrm{C}$ & $366 \pm 87.6$ & $536 \pm 120$ & $519 \pm 49.7$ & $348 \pm 87.7$ & $221 \pm 164$ & $191 \pm 82$ & $321 \pm 336$ \\
\hline \multirow{4}{*}{ Pinchen } & CK & $12.6 \pm 3.0$ & $2.7 \pm 2.6$ & $2.6 \pm 1.9$ & $2.8 \pm 2.0$ & $3.6 \pm 2.2$ & $5.5 \pm 2.0$ & $3.3 \pm 1.2$ \\
\hline & A & $8.2 \pm 2.5$ & $1.3 \pm 0.7$ & $2.3 \pm 0.7$ & $0.9 \pm 0.4$ & $3.6 \pm 3.2$ & $4.2 \pm 1.9$ & $3.9 \pm 2.5$ \\
\hline & B & $5.8 \pm 2.8$ & $3.0 \pm 1.1$ & $8.8 \pm 6.5$ & $1.0 \pm 0.7$ & $3.1 \pm 1.3$ & $3.7 \pm 5.2$ & $4.5 \pm 4.5$ \\
\hline & $\mathrm{C}$ & $13.6 \pm 6.8$ & $2.9 \pm 1.4$ & $9.7 \pm 9.7$ & $1.8 \pm 1.2$ & $3.7 \pm 0.0$ & $8.5 \pm 10.5$ & $3.4 \pm 2.6$ \\
\hline
\end{tabular}

CK: aerobic treatment for 10 days after rice seedling; A: aerobic treatment for 3 weeks before rice heading; $\mathrm{B}$ : aerobic treatment for 3 weeks after rice heading; $\mathrm{C}$ : aerobic treatment for 3 weeks before rice heading and continue for another 3 weeks after rice heading.

Table 3. Comparison of As concentration in husk and brown rice cultivated from two soils and four water management strategies.

\begin{tabular}{|c|c|c|c|c|}
\hline Soil & $\begin{array}{c}\text { Water } \\
\text { treatments } \emptyset\end{array}$ & $\begin{aligned} \text { Husk } \\
\\
\text {------- }\end{aligned}$ & \multicolumn{2}{|c|}{ Brown rice } \\
\hline Erlin & $\mathrm{CK}$ & \multicolumn{3}{|c|}{$\begin{array}{cc}--1.44 \pm 0.30 \mathrm{a} \& & 0.48 \pm 0.11 \mathrm{~b} \&\end{array}$} \\
\hline \multirow{7}{*}{ PinChen } & A & $0.92 \pm 0.20 \mathrm{~b}$ & $0.43 \pm 0.08$ & $\mathrm{~b}$ \\
\hline & B & $1.50 \pm 0.31 \mathrm{a}$ & $0.76 \pm 0.29 \mathrm{a}$ & \\
\hline & $\mathrm{C}$ & $0.85 \pm 0.12 b$ & $0.37 \pm 0.04$ & $\mathrm{~b}$ \\
\hline & CK & $0.55 \pm 0.09 \mathrm{a}$ & $0.33 \pm 0.05$ & $\mathrm{a}$ \\
\hline & A & $0.44 \pm 0.02 \mathrm{~b}$ & $0.28 \pm 0.03$ & $\mathrm{a}$ \\
\hline & B & $0.53 \pm 0.05$ & $0.29 \pm 0.04$ & $\mathrm{a}$ \\
\hline & $\mathrm{C}$ & $0.39 \pm 0.004 b$ & $0.25 \pm 0.03$ & $\mathrm{a}$ \\
\hline
\end{tabular}

T: $\mathrm{CK}$ : aerobic treatment for 10 days after rice seedling; A: aerobic treatment for 3 weeks before rice heading; $\mathrm{B}$ : aerobic treatment for 3 weeks after rice heading; C: aerobic treatment for 3 weeks before rice heading and continue for another 3 weeks after rice heading.

\&: The data are the mean value and standard deviation of four replicates. Statistical result, which was significant difference among the treatments at $p=0.05$ based on Fisher's LSD, were denoted in parentheses letter.

Fe (McKeague and Day, 1966), free Fe (Mehra and Jackson, 1960), and total As (Meharg and Rahman, 2003). Soils were spiked additional As $20 \mathrm{mg} / \mathrm{kg}$ with sodium arsenate hydrates $\left(\mathrm{Na}_{2} \mathrm{HAsO}_{4} \cdot 7 \mathrm{H}_{2} \mathrm{O}\right)$ and then aging for four mouths by the cycling of reduction and oxidation processes.

Pot experiment, with four replications for each treatment, was conducted to evaluate the effects of water management on As in brown rice for two soils. Rice (Oryza sativa L. cv. Tainan 11) was germinated before 2 weeks of seedling. Basal fertilizers $(0.78 \mathrm{~g}$ urea, $0.64 \mathrm{~g}$ $\mathrm{Ca}\left(\mathrm{H}_{2} \mathrm{PO}_{4}\right)_{2} \cdot \mathrm{H}_{2} \mathrm{O}$, and $\left.0.23 \mathrm{~g} \mathrm{KCl}\right)$ was applied into pots before 10 days of transplantation, the $0.47 \mathrm{~g}$ urea and $0.23 \mathrm{~g} \mathrm{KCl}$ as supporting fertilizer was supplied at the 
$20^{\text {th }}$ day, and $0.32 \mathrm{~g}$ urea and $0.12 \mathrm{~g} \mathrm{KCl}$ was supplied at the $55^{\text {th }}$ day after transplantation.

Four water management treatments were designed in this experiment: (1) maintaining soil moisture in aerobic condition (Eh ranged $0-200 \mathrm{mV}$ ) for 10 days after maximum tillering ( 35 days of rice seedling, control treatment, denoted as CK); (2) maintaining soil moisture in aerobic condition for 3 weeks before rice heading (82 days after transplant, denoted as treatment A); (3) maintaining soil moisture in aerobic condition for 3 weeks after rice heading (denoted as treatment B); and (4) maintaining soil moisture in aerobic condition for 3 weeks before rice heading and continue for another 3 weeks after rice heading (60-102 days after transplant, denoted as treatment C). During the experiment period, the soil redox potential (Eh) was monitored by ORP platinum electrode with portable monitor, and soil solution was collected at the day of $1^{\text {st }}, 34^{\text {th }}, 48^{\text {th }}, 60^{\text {th }}$, $82^{\text {nd }}, 104^{\text {th }}$ and $117^{\text {th }}$ by RSMS soil solution collector after seedling. The soil solution was acidified with $\mathrm{HNO}_{3}$ and then the As concentration was determined by hydride generation atomic absorption spectrometer (Perkin-Elmer AAnalyst 200 fitted with flow infection system, FIAS 400).

Harvested rice plants were cut at $5 \mathrm{~cm}$ above soil surface. After drying and weighting, the harvested grain was separated into husk and brown rice. Each part was ground and digested with $\mathrm{HNO}_{3}$ and $\mathrm{H}_{2} \mathrm{O}_{2}$. As concentration of brown rice and husk were determined by ICP-MS. ANOVA and Fisher's LSD test were used to compare the As content among the different water managements.

\section{Results and Discussion}

The Pinchen soil, classified as Oxisol based on USDA Soil Taxonomy, had much higher free $\mathrm{Fe}$ and $\mathrm{Al}$ content than that of Erlin soil classified as Inceptisol (Table 1). Clay content of Pinchen soil was $44.4 \%$, but only $20.5 \%$ of clay in Erlin soil. It was suggested that Pinchen soil had higher As sorption capacity than Erlin soil. Besides, higher soil organic matter level was benefit to produce soil reduction condition under flooding environment (Yamaguchi et al., 2010), and the environment maybe change to arsenite or organic As species concentration increasing in soil solution (Somenahally et al., 2011). In this study, the As concentration of soil solution was 10 to 20 folds in Erlin soil than that of Pinchen soil, and the As concentration elevating stably during the early stage of experiment period (0-60 days) (Table 2), this result can be contributed by the lower As sorption capacity and higher soil organic matter content in Erlin soil.

During the aerobic condition of the treament, the As concentration of Erlin soil solution ranged 108-220 $\mu \mathrm{g} / \mathrm{L}$, which was only $30-50 \%$ of original As concentration in Erlin soil solution comparing to flooding period (Table 2). However, there was no significant difference on As concentration among 4 water management treatments during aerobic and anaerobic conditions of Pinchen soil (Figure 1). Therefore, These results indicated that both soil properties and water management do effect the As concentration in soil solution.

Growing rice aerobically on specific rice growing period will significantly reduce the As level of brown rice but not affect the grain yield obviously for rice grown at As-contaminated site. Xu et al. (2008) showed that growing paddy rice aerobically would decrease rice As level markedly. However, for rice cultivated in the subtropics area, insufficient irrigation may lead to significant rice yield decline (Peng et al., 2005). Arao et al. (2009) reported that total As concentration of rice grain, which taking 3 weeks of aerobic treatment before or after rice heading, was 0.30 and $0.36 \mathrm{mg} / \mathrm{kg}$, and the rice which has 6 weeks aerobic treatment contained only $0.11 \mathrm{mg} / \mathrm{kg}$. It was worthy to note that the difference of grain yield in the previous studies was not obvious.

In this pot experiment, brown rice grown in Erlin soil had As level 0.43 and $0.37 \mathrm{mg} / \mathrm{kg}$ in treatment A and $\mathrm{C}$, that were significantly lower than treatment $\mathrm{B}$. However, As level of brown rice between treatment $\mathrm{A}$ and $\mathrm{C}$ showed no significant difference (Table 3 ). This discrepancy can be explained by the cultivar difference comparing to other studies. The conventional water management (CK) showed higher As level in husk but no significant difference in brown rice compared to other three aerobic treatments. This difference can be explained by the rice physiologic mechanism (Norton et al., 2010).

Water management effecting on the grain yield was observed in Pinchen soil but not significant in Erlin soil (Figure 1). The grain yield was much lower in Erlin soil than that of Pinchen soil, which means rice grown in As-contaminated Erlin soil might produce some degree of toxic adversity. Although the aerobic management do not significantly reduce the grain yield, but the aerobic treatments can inhibit the As concentration in brown rice in this study.

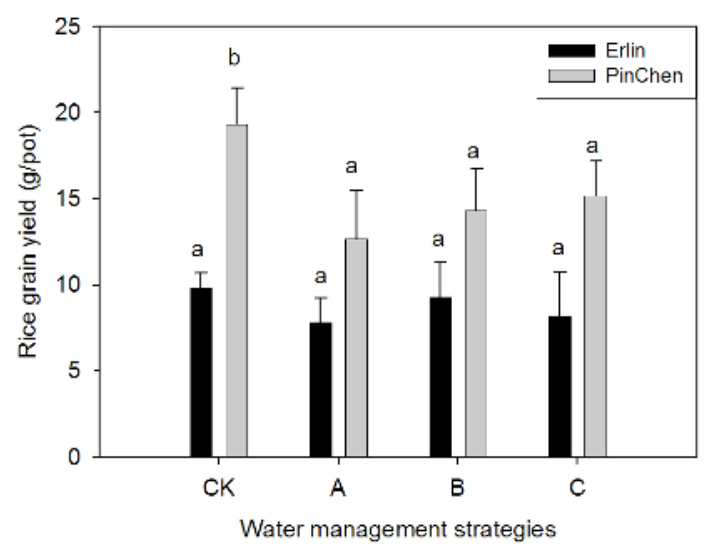

Fig. 1. Comparison of grain yield of two soils at 4 water management treatments. The letter represents significant differences among different treatments at $p=0.05$ according to the Fisher's LSD. 


\section{Conclusion}

The water management effect on the As level of brown rice was different between two studied soils in this study. Conventional water management treatment (CK) in Taiwan or soil aerobic treatment for 3 weeks before rice heading can produce lower As level in brown rice than that of soil aerobic treatment for 3 weeks after rice heading. However, there was no significant difference in brown rice As level for all treatments in As-contaminated Pinchen soil, this phenomena may be attributed to higher clay content or free $\mathrm{Fe}$ and $\mathrm{Al}$ content in the soil.

\section{References}

Arao T, Kawasaki A, Baba K, Mori S, Matsumoto S. Effects of water management on cadmium and arsenic accumulation and dimethylarsinic acid concentrations in Japanese rice. Environ. Sci. Technol. 2009; 43:9361-9367.

Chen CJ, Wang SL, Chiou JM, Tseng CH, Chiou HY, Hsueh YM, Chen SY, Wu MM, Lai MS. Arsenic and diabetes and hypertension in human populations: A review. Toxicol Appl Pharm 2007; 222:298-304.

Gee GW, Bauder JW. Particle-size analysis. In: Klute A, editor. Methods of soil analysis, Part 2, 2nd ed. Madison, WI, USA: ASA and SSSA, 1986. p. 384-411.

Hsu WM, Hsi HC, Huang YT, Liao CS, Hseu ZY. Partitioning of arsenic in soil-crop systems irrigated using groundwater: A case study of rice paddy soils in southwestern Taiwan. Chemosphere 2012; 86:606-613.

McKeague JA, Day JH. Dithionite- and oxalate-extractable $\mathrm{Fe}$ and $\mathrm{Al}$ as aids in differentiating various classes of soils. Can J Soil Sci 1966; 46:13-22.

Meharg AA, Rahman MM. Arsenic contamination of Bangladesh paddy field soils: Implication for rice contribution to arsenic consumption. Environ Sci Technol 2003; 37:229-234.
Mehra OP, Jackson ML. Iron oxides removal from soils and clays by a dithionite-citrate system buffered with sodium bicarbonate. Clays Clay Miner 1960; 7:317-327.

Norton GJ, Islam MR, Duan GL, Lei M, Zhu YG, Deacon CM, Moran AC, Islam S, Zhao FJ, Stroud JL, McGrath SP, Feldmann J, Price AH, and Meharg AA. Arsenic shoot-grain relationships in field grown rice cultivars. Environ Sci Technol 2010; 44:1471-1477.

Peng SB, Bouman B, Visperas RA, Castaneda A, Nie LX, Park HK. Comparison between aerobic and flooded rice in the tropics: Agronomic performance in an eight-season experiment. Field Crop Res 2006; 96:252-259.

Somenahally AC, Hollister EB, Yan WG, Gentry TJ, Loeppert RH. Water management impacts on arsenic speciation and iron-reducing bacteria in contrasting rice-rhizosphere compartments. Environ Sci Technol 2011; 45:8328-8335.

$\mathrm{Su} \mathrm{SW}$, Chen ZS. Impacts of arsenic contaminated soils on agroecosystem in Guandu plain, Taipei: assessment by As fractionation. Proceedings of $14^{\text {th }}$ International Conference on Heavy Metals in the Environment (14th ICHMET). November 16-23, 2008; pp. 93-96. National Taiwan University, Taipei, Taiwan.

Thomas GW. Soil pH and soil acidity. In: Sparks DL et al. (editors). Methods of soil analysis, Part 3. Madison, WI, USA: ASA and SSSA, 1996, pp.475-490.

Walkley A, Black IA. An examination of different methods for determining soil organic carbon matter and a proposed modification of the chromic acid titration method. Soil Sci 1934; 37:29-38.

$\mathrm{Xu}$ XY, McGrath SP, Meharg AA, Zhao FJ. Growing rice aerobically markedly decreases arsenic accumulation. Environ. Sci. Technol. 2008; 42 (15): 5574-5579.

Yamaguchi N, Nakamura T, Dong D, Takahashi Y, Amachi S, Makino T. Arsenic release from flooded paddy soils is influenced by speciation, $\mathrm{Eh}, \mathrm{pH}$, and iron dissolution. Chemosphere 2011; 83:925-932. 